\title{
DAMPAK KEPUTUSAN BERWIRAUSAHA DENGAN LINGKUNGAN SOSIAL DAN PENDIDIKAN FORMAL PADA MOTIVASI BERWIRAUSAHA
}

\author{
SEPTIANA NOVITA DEWI \\ Sekolah Tinggi Ilmu Ekonomi AUB Surakarta \\ Email: novitadewi@yahoo.co.id \\ ARIS TRI HARYANTO \\ Sekolah Tinggi Ilmu Ekonomi AUB Surakarta \\ Email: Arisharyanto26@yahoo.co.id
}

\begin{abstract}
Abstrak
Seorang wirausahawan adalah seorang yang memiliki keahlian untuk menjual, mulai dari menawarkan ide hingga komoditas baik berupa produk atau jasa, sehingga untuk menumbuhkan motivasi berwirausaha perlu dilakukan penelitian lebih lanjut. Penelitian ini bertujuan untuk mengetahui dampak keputusan berwirausaha dengan lingkungan sosial dan pendidikan formal pada motivasi berwirausaha (Studi pada Pencari Kerja Job Fair di Teknopark Sragen). Teknik analisis yang digunakan adalah path analysis yang menggunakan sampel sebanyak 50 responden pada bulan Nopember 2016 di Job Fair di Teknopark Sragen. hasil penelitian menunjukkan lingkungan sosial berpengaruh negatif dan tidak signifikan terhadap motivasi berwirausaha. Pendidikan formal berpengaruh positif dan tidak signifikan terhadap motivasi berwirausaha. Lingkungan sosial berpengaruh negatif dan tidak signifikan terhadap keputusan berwirausaha. Pendidikan formal berpengaruh positif dan tidak signifikan terhadap keputusan berwirausaha. Motivasi berwirausaha berpengaruh positif dan signifikan terhadap keputusan berwirausaha. Hasil analisis jalur menunjukkan bahwa: pengaruh tidak langsung lingkungan sosial terhadap keputusan berwirausaha melalui motivasi berwirausaha menghasilkan pengaruh yang lebih besar dari pada pengaruh langsung. pengaruh tidak langsung pendidikan formal terhadap keputusan berwirausaha melalui motivasi berwirausaha menghasilkan pengaruh yang lebih kecil dari pada pengaruh langsung.
\end{abstract}

Kata kunci: Keputusan Berwirausaha, Lingkungan Sosial, Pendidikan Formal, Motivasi berwirausaha.

\section{PENDAHULUAN}

Banyaknya masyarakat yang semakin sulit untuk menemukan lapangan pekerjaan pada masa kini menimbulkan banyak sekali pengangguran khususnya

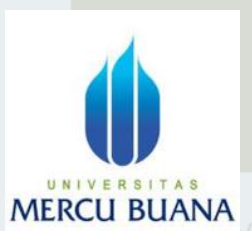

MERCU BUANA

Jurnal Perilaku Dan Strategi bisnis

Vol.5 No.1, 2017

Hal. $109-116$ di Indonesia. Jumlah pencari kerja yang banyak tidak sebanding dengan ketatnya dalam seleksi pekerjaan yang terbatas. Bahkan orang-orang yang bergelar sarjanapun sekarang ini bukan menjadi jaminan untuk mendapatkan pekerjaan yang sesuai dengan degree mereka. Dampaknya adalah banyak para pelamar kerja yang mendapat suatu pekerjaan yang tidak sesuai dengan pendidikan mereka, mendapatkan pekerjaan yang tidak layak, atau bahkan akan menjadi pengangguran yang tentunya sangat ditakuti oleh 
para pencari kerja. Keputusan berwirausaha merupakan sesuatu yang membangkitkan perhatian pada suatu hal. Minat mengindikasikan apa yang diinginkan atau dilakukan orang atau apa yang mereka senangi. Seseorang yang berminat pada suatu hal, maka segala tindakan atau apa yang dilakukan akan mengarahkannya pada minatnya tersebut.

Penelitian ini timbul karena adanya permasalahan atau fenomena yang terjadi. Hal ini seperti adanya sebuah pertanyaan, mengapa pencari kerja bergantung dengan lapangan pekerjaan yang sudah ada, dan mengapa para pencari kerja tidak menciptakan lapangan kerja baru dengan berwirausaha. Hal ini sesuai dengan fakta bahwa keputusan untuk berwirausaha masih sangat sedikit atau bahkan kurang, hal ini dikarenakan kurangnya motivasi untuk berwirausaha.

Motivasi untuk mengikuti untuk mengikuti pelatihan berwirausaha, karena dengan mengikuti pelatihan akan menimbulkan minat berwirausaha. Dorongan orang tua akan sangat beerarti, karena orang tua dapat memberikan saran untuk dapat mencari pekerjaan agar menodorong anak untuk menciptakan lapangan kerja baru dengan menjadi seorang wirausaha. Faktor lingkungan sosial dan pendidikan formal juga mempengaruhi minat berwirausaha. Purnamawati (2009).

Di Indonesia sangat sulit untuk mendapatkan pekerjaan. Hal ini semakin memperparah keadaan ekonomi bangsa dengan timbulnya penangguran yang ada. Oleh karena itu, di dalam perekonomian negara berwirausaha merupakan alas an betapa pentingnya hal tersebut dikembangkan. Akhirnya, banyak orang yang berusaha untuk mendapatkan pekerjaan dengan cara salah satunya adalah mendirikan usaha sendiri atau yang lebih dikenal sebagai berwirausaha. Menurut Purnamawati (2009) menjadi pengusaha merupakan alternatif pilihan yang tepat. Paling tidak, dengan berwirausaha berarti menyediakan lapangan kerja bagi diri sendiri dan tidak bergantung pada orang lain.

Seorang wirausahawan adalah seorang yang memiliki keahlian untuk menjual, mulai dari menawarkan ide hingga komoditas baik berupa produk atau jasa. Seorang wirausahawan (entrepreneur) adalah seseorang yang menciptakan bisnis baru dengan mengambil risiko dan ketidakpastian demi mencapai keuntungan dan pertumbuhan dengan cara mengidentifikasi peluang yang signifikan dan menggabungkan sumber-sumber daya yang diperlukan sehingga sumber-sumber daya itu bisa dikapitalisasikan (Zimmerer, 2008).

Dengan kreativitasnya, wirausahawan mampu beradaptasi dengan berbagai situasi dan kondisi lingkungan. Sebagai pelaku bisnis, wirausahawan harus mengetahui dengan baik manajemen penjualan, gaya dan fungsi manajemen. Untuk berhasil, ia harus mampu berkomunikasi dan menguasai beberapa elemen kecakapan manajerial, serta mengetahui teknik menjual yang strategis mulai dari pengetahuan tentang produk, ciri khas produk dan daya saing produk terhadap produk sejenis (Mahesa, 2012). Begitu pula yang dikatakan oleh Rye (2005) bahwa seorang wirausahawan adalah seorang yang mengorganisasikan dan mengarahkan usaha baru. Wirausahawan berani mengambil risiko yang terkait dengan proses pemulaian.

Kewirausahaan dapat diajarkan melalui pendidikan dan pelatihan. "entrepreneurship has models, processes, and case studies that allow the topic to be studied and the knowledge to be acquired" (Kuratko \& Hodgetts, 2007: 34). Realita di lapangan, sistem pembelajaran saat ini belum sepenuhnya secara efektif membangun peserta didik memiliki akhlak mulia dan karakter bangsa termasuk karakter wirausaha. Proses pembelajaran di SMK belum 
sepenuhnya mampu membangun potensi kepribadian wirausaha. Hal ini antara lain ditunjukkan dengan jumlah pengangguran yang relatif tinggi, jumlah wirausaha yang masih relatif sedikit, dan terjadinya degradasi moral (Kemendiknas, 2010).

Pembekalan pengetahuan kewirausahaan kepada masyarakat khususnya masyarakat Kabupaten Karanganyar sangat perlu dilakukan. Semakin tinggi pengetahuan kewirausahaan masyarakat Kabupaten Karanganyar akan semakin terbuka wawasannya tentang kewirausahaan. Hasil-hasil penelitian Eka (2013) menyimpulkan bahwa pengetahun kewirausahaan berpengaruh terhadap keputusan berwirausaha.

Selain pendidikan formal di lingkungan sekolah dan lingkungan sosial, dan dorongan keluarga terutama orang tua juga berperan penting sebagai pengarah bagi masa depan anaknya, sehingga secara tidak langsung orang tua juga dapat mempengaruhi minat terhadap pekerjaan bagi anak di masa yang akan datang, termasuk dalam hal berwirausaha. Menurut Wasty Soemanto (2008:38) menyatakan, "Orang tua atau keluarga juga merupakan peletak dasar bagi persiapan anak-anak agar dimasa yang akan datang dapat menjadi pekerja yang efektif". Dalam mendidik anak, para orang tua harus mengajarkan anaknya memotivasi diri untuk bekerja keras, diberi kesempatan untuk bertanggung jawab atas apa yang dia lakukan. Orang tua yang berwirausaha dalam bidang tertentu dapat menimbulkan minat anaknya untuk berwirausaha dalam bidang yang sama.

Akan tetapi, untuk menjadi pengusaha tidak bisa diraih dalam waktu singkat. Potensi dan kemampuan yang ada, perlu diasah sejak dini. Bimbingan dan pelatihan yang berkelanjutan bagi calon entrepreneur muda berbakat juga perlu dilakukan. Kewirausahaan bukan keturunan akan tetapi dapat dihasilkan melalui pendidikan dan pelatihan. Pendidikan dan pelatihan kewirausahaan meliputi dua aspek yaitu pendidikan mental dan kemampuan atau keahlian (Sunarya, 2011).

Berdasarkan masalah penelitian yang telah dikemukakan peneliti-peneliti di atas serta fenomena-fenomena yang terjadi di Kabupaten Karanganyar yang merupakan salah satu program Job Fair di Teknopark Sragen, maka Penulis mengambil judul: "Dampak Keputusan Berwirausaha dengan Lingkungan Sosial dan Pendidikan Formal pada Motivasi Berwirausaha (Studi pada Pencari Kerja Job Fair di Teknopark Sragen).

\section{LANDASAN TEORI}

\section{Kewirausahaan}

An interest can be defined as something that arouses or holds one's attention or curiosity. Interests are indications of what individuals want to do or what they enjoy or like" (Brown \& Brooks, 2010). Keputusan dapat didefinisikan sebagai sesuatu yang membangkitkan perhatian pada suatu hal. Keputusan berwirausaha mengindikasikan apa yang diinginkan atau dilakukan orang atau apa yang mereka senangi. Seseorang yang berminat pada suatu hal, maka segala tindakan atau apa yang dilakukan akan mengarahkannya pada minatnya tersebut.

Keputusan berwirausaha merupakan tingkat kegairahan yang menyertai perhatian khusus maupun terus menerus kepada suatu objek, peristiwa atau topik tertentu minat sangat dipengaruhi oleh dua variabel, yaitu: variabel sikap dan norma subyektif. Dengan kata lain, gabungan dari variabel sikap dan norma subyektif tidak akan langsung mempengaruhi 
perilaku, melainkan beroperasi terlebih dahulu melalui minat, dan minat inilah yang akan berpengaruh langsung pada perilaku (Setiawan, 2011).

\section{Motivasi}

Menurut Gibson (2006), motivasi merupakan kekuatan yang mendorong seseorang yang menimbulkan dan mengarahkan perilaku. Motivasi adalah keadaan dalam pribadi seseorang yang mendorong keinginan individu untuk melakukan kegiatan-kegiatan tertentu guna mencapai tujuan. Motivasi yang ada pada seseorang akan mewujudkan suatu perilaku yang diarahkan pada tujuan mencapai sasaran kepuasan. Motivasi bukanlah yang dapat diamati tetapi adalah hal yang dapat disimpulkan adanya karena sesuatu perilaku yang tampak.

Menurut Luthans, (2006), motivasi merupakan proses untuk mencoba mempengaruhi seseorang agar melakukan sesuatu yang kita inginkan. Motivasi merupakan hal yang melatarbelakangi individu berbuat untuk mencapai tujuan tertentu. Seseorang yang dengan sengaja mengikatkan diri menjadi bagian dari organisasi mempunyai latar belakang yang berbeda-beda, salah satunya adalah agar mereka dapat berinteraksi dengan manusia lainnya dan agar kebutuhan hidupnya dapat terpenuhi. Mangkunegara (2006) bahwa "Motivation as an energizing condition of the organism that serves to direct that organism toward the goal of a certain class", motivasi sebagai suatu kondisi yang menggerakkan manusia kearah suatu tujuan tertentu.

\section{Lingkungan Sosial}

Menurut Wibowo (2011) lingkungan sosial merupakan lingkungan masyarakat dimana terjadi interaksi antara individu satu dengan yang lain, individu dengan kelompok, atau kelompok dengan kelompok. Lingkungan sosial ini ada yang primer dan ada yang sekunder. Lingkungan primer terjadi bila di antara individu yang satu dengan yang lain mempunyai hubungan yang erat dan saling mengenal dengan baik, misalnya keluarga. Lingkungan demikian akan mempunyai pengaruh yang mendalam terhadap perkembangan individu.

Menurut Ibnoe (1993), karena kemampuan afektif mencakup sikap, nilai, aspirasi, perasaan, dan emosi yang semuanya sangat bergantung pada kondisi lingkungan yang ada, maka dimensi kemampuan afektif dan kemampuan kognitif merupakan bagian dari pendekatan kemampuan kewirausahaan.

Faktor lingkungan dapat mempengaruhi individu yang ada di dalam organisasi. Lingkungan manajemen SDM dapat didefinisikan sebagai serangkaian faktor yang mempengaruhi kinerja dari aktivitas manajemen sumber daya manusia yang terdiri dari faktor internal dan eksternal (Arif, 2012).

\section{Pendidikan Formal}

Pendidikan formal seperti di sekolah menjadi tanggung jawab guru. Jadi pada dasarnya yang berpengaruh terhadap perkembangan masyarakat yaitu proses pendidikan di sekolah sebagai bekal untuk diterapkan dalam kehidupan di lingkungan masyarakat. Seorang guru dalam proses pendidikan juga dapat memberikan motivasi dan dorongan kepada masyarakat dalam menumbuhkan minatnya. Sebagai pendidik dalam lembaga pendidikan formal, maka guru berperan untuk mencerdaskan kehidupan bangsa, apalagi yang dibutuhkan orang pada dasarnya adalah ke arah pengembangan kualitas SDM yang berguna (Suprapto, 2007).

Berkaitan dengan pendidikan formal, Henry dan Thompson mendefiniskan pendidikan kejuruan dalam Berg (2002:45) sebagai berikut: Vocational education is "learning how to 
work", vocational education has been an effort to improve technical competence and to raise an individual's position in society through mastering his environment with technology. Additionally, vocational education is geared to the needs of the job market and thus is often seen as contribution to national economic strength.

Inti dari pendapat Berg bahwa pendidikan kejuruan itu identik dengan belajar bagaimana untuk bekerja, pendidikan kejuruan berupaya meningkatkan tehnik dan posisi seseorang di lingkungannya melalui penguasaan tehnologi dan pendidikan kejuruan berkaitan erat dengan kebutuhan pasar kerja dan karena itu sering dipandang sebagai sesuatu yang memberikan kontribusi yang kuat terhadap ekonomi yang minimal.

\section{KERANGKA KONSEPTUAL}

Kerangka konseptual yang diajukan dalam penelitian ini adalah sebagai berikut:

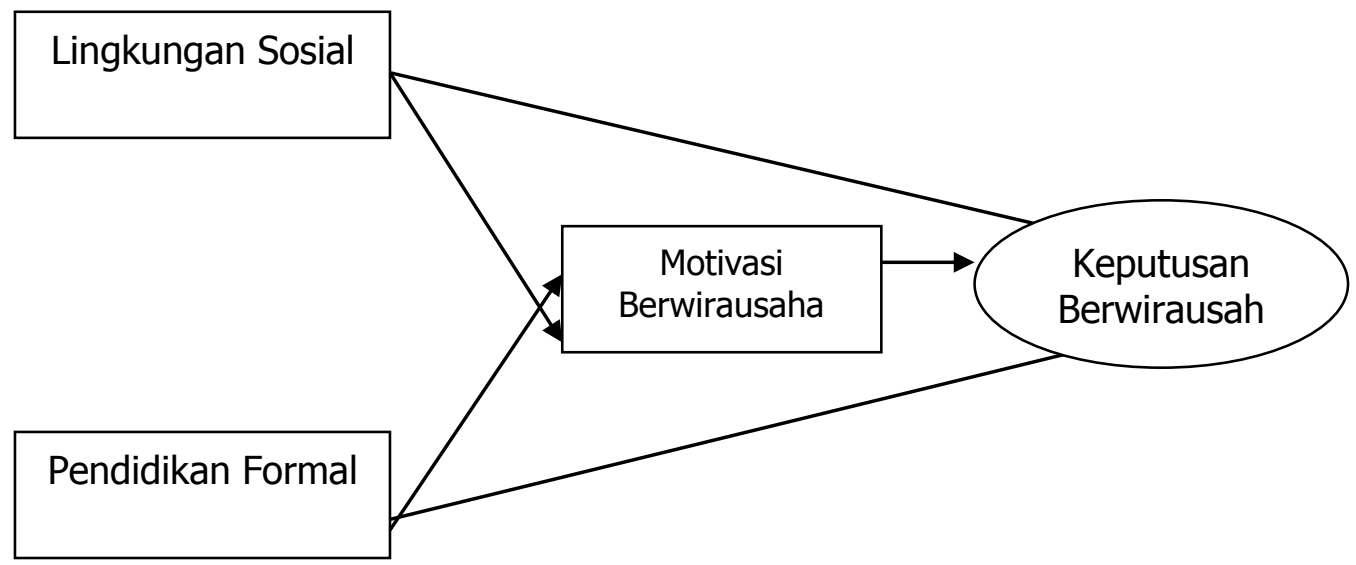

Gambar. 1. Kerangka Konseptual

Sumber: Hanum Risfi Mahanani, (2014), Eka Aprilianty. (2014), Putu et.,al (2014), Singgih Purnomo, (2013), Lee, M. S. (2005)

\section{METODE PENELITIAN}

Penelitian populasi dilakukan apabila seseorang ingin meneliti semua elemen yang ada dalam wilayah penelitian. Studi atau penelitiannya juga disebut studi populasi atau studi sensus (Arikunto, 2001:109). Populasi dalam penelitian ini adalah yang mencari kerja di Job Fair di Teknopark Sragen pada bulan Nopember 2016 sekitar 500 responden. Menurut Arikunto (2007:120), jika jumlah subyeknya (populasinya) kurang dari 100 sampel maka sebaiknya semua populasi diambil sebagai sampel penelitian, jika sampelnya lebih dari 100, maka dapat ditentukan berdasarkan prosentase, misalnya $10 \%-20 \%$ atau $20 \%-30 \%$, menurut kemampuan peneliti. Sampel dalam penelitian ini adalah sebesar $10 \%$ dari populasi yaitu sebesar 50 responden pada bulan Nopember 2016 di Job Fair di Teknopark Sragen, Teknik analisis dalam penelitian ini adalah analisis jalur. Analisis jalur memperhitungkan pengaruh langsung dan tidak langsung maupun pengaruh total. Diagram jalur berikut menunjukkan pengaruh langsung dan tidak langsung maupun pengaruh total.

Tabel 1. Pengaruh Langsung, Pengaruh Tidak Langsung dan Total Pengaruh 


\begin{tabular}{clll}
\hline \multirow{2}{*}{ Dari Variabel } & \multicolumn{2}{c}{ Koefisien Jalur } & \\
& (Direct Effect) & (Indirect Effect) & \\
\hline $\mathrm{X}_{1}$ ke $Y$ & $\mathrm{P}_{3}=-0,011$ & & \\
$\mathrm{X}_{2}$ ke $\mathrm{Y}$ & $\mathrm{P}_{4}=0,231$ & & \\
$\mathrm{X}_{1}$ melalui $\mathrm{X}_{5}$ Ke $\mathrm{Y}$ & & $\mathrm{P}_{1} \times \mathrm{P}_{5}=$ & $\mathrm{P}_{3}+\left(\mathrm{P}_{1} \times \mathrm{P}_{5}\right)=$ \\
& & $-0,011 \times 0,599$ & $-0,011+(-0,007)$ \\
& & $=-0,007$ & $=-0,018$ \\
$\mathrm{X}_{2}$ melalui $\mathrm{X}_{5} \mathrm{Ke} \mathrm{Y}$ & & $\mathrm{P}_{2} \times \mathrm{P}_{5}=$ & $\mathrm{P}_{4}+\left(\mathrm{P}_{2} \times \mathrm{P}_{5}\right)=$ \\
& & $0,179 \times 0,599$ & $0,231+0,107$ \\
& & $=0,107$ & $=0,338$ \\
\hline
\end{tabular}

Sumber: Data diolah 2016

\section{PEMBAHASAN}

1. Pengaruh lingkungan sosial terhadap keputusan berwirausaha

Penggunaan variabel lingkungan sosial terhadap motivasi berwirausaha tidak signifikan. Demikian juga pengaruh langsung lingkungan sosial terhadap keputusan berwirausaha berpengaruh tidak signifikan. Dengan demikian lingkungan sosial tidak direkomendasikan sebagai variabel prediktor untuk mempengaruhi pencari kerja agar mengambil keputusan untuk berwirausaha.

2. Pengaruh pendidikan formal terhadap keputusan berwirausaha

Penggunaan variabel pendidikan formal terhadap motivasi berwirausaha tidak signifikan. Demikian juga pengaruh langsung pendidikan formal terhadap keputusan berwirausaha berpengaruh tidak signifikan. Dengan demikian pendidikan formal tidak direkomendasikan sebagai variabel prediktor untuk mempengaruhi pencari kerja agar mengambil keputusan untuk berwirausaha.

\section{KESIMPULAN}

1. Lingkungan sosial berpengaruh negatif dan tidak signifikan terhadap motivasi berwirausaha Pencari kerja di Job Fair di Teknopark Sragen.

2. Pendidikan formal berpengaruh positif dan tidak signifikan terhadap motivasi berwirausaha Pencari kerja di Job Fair di Teknopark Sragen.

3. Lingkungan sosial berpengaruh negatif dan tidak signifikan terhadap keputusan berwirausaha Pencari kerja di Job Fair di Teknopark Sragen.

4. Pendidikan formal berpengaruh positif dan tidak signifikan terhadap keputusan berwirausaha Pencari kerja di Job Fair di Teknopark Sragen.

5. Motivasi berwirausaha berpengaruh positif dan signifikan terhadap keputusan berwirausaha Pencari kerja di Job Fair di Teknopark Sragen.

6. Hasil uji $\mathrm{F}$ dapat disimpulkan secara bersama-sama variabel bebas mempengaruhi Keputusan berwirausaha pencari kerja.

7. Nilai R2 total sebesar 0,768, dapat diartikan variabel keputusan berwirausaha Pencari kerja di Job Fair di Teknopark Sragen dijelaskan oleh variabel pelatihan, dorongan keluarga, lingkungan sosial, pendidikan formal dan motivasi berwirausaha sebesar $76,8 \%$ dan sisanya $23,2 \%$ dijelaskan variabel lain diluar model penelitian sebagai contoh pengetahuan teknologi, pengalaman pencari kerja dan sebagainya. 
8. Hasil analisis jalur menunjukkan bahwa:

a. Pengaruh tidak langsung lingkungan sosial terhadap keputusan berwirausaha melalui motivasi berwirausaha menghasilkan pengaruh yang lebih besar dari pada pengaruh langsung.

b. pengaruh tidak langsung pendidikan formal terhadap keputusan berwirausaha melalui motivasi berwirausaha menghasilkan pengaruh yang lebih kecil dari pada pengaruh langsung.

\section{SARAN}

Berdasarkan hasil penelitian yang telah dilakukan, maka dapat disarankan hal-hal sebagai berikut:

1. Untuk menyelenggarakan pelatihan yang mampu meningkatkan motivasi berwirausaha maka Job Fair di Teknopark Sragen dapat menjalin kerjasama dengan lembaga-lembaga pelatihan motivasi.

2. Membantu para pencari kerja yang telah mengikuti pelatihan dengan memberikan bantuan sarana dan prasarana untuk memulai wirausaha yang diminati oleh para pencari kerja.

\section{REKOMENDASI}

Selain pelatihan yang mampu meningkatkan motivasi berwirausaha, maka untuk peneliti berikutnya perlu mengadakan penelitian dengan menambah variabel-variabel yang lain yang dapat meningkatkan pengambilan keputusan bagi pencari kerja, misalnya modal usaha, kreativitas, kesempatan kerja, usia dan lain sebagainya.

\section{REFERENSI}

Alma, B. (2004). Kewirausahaan Penuntun Perkuliahan untuk Perguruan Tinggi. Bandung: Alfabeta.

Arikunto Suharsimi, A. (2010). Dasar-dasar Evaluasi Pendidikan. Jakarta: Bumi Aksara

Brown, Duane \& Brooks, Linda. (2010). Caree Counseling Techniques. Boston: Allyn And Bacon

Cuervo, A., Ribeiro, D., \& Roig, S. (2010). Entrepreneurship: Concepts, Theory and Perspective. Springer.

Djarwanto dan Subagyo, Pangestu, 2001: Statistik Induktif, Edisi: 4, Yogyakarta: BPFE

Downey, W.D. \& Erickson, S.P. (2007) Manajemen Agribisnis. (Terjemahan Rochidayat Ganda \& Alfonsus Sirait). Jakarta: Penerbit Erlangga. (Buku Asli Agribusiness Management diterbitkan tahun 1987)

Eka Aprilianty. 2014. Pengaruh Kepribadian Wirausaha, Pengetahuan Kewirausahaan, pendidikan formal Dan Lingkungan Terhadap Minat Berwirausaha Siswa SMK Jurnal Managemen Pangkalan Bun, Kalimantan Tengah

Ghozali, Imam,2005. Aplikasi Analisis Multivariate Dengan Program SPSS 
Gnyawali, D. R. (1994). Environments for Entrepreneurship Development: Key Dimensions and Research Implications. Baylor University

Hanum Risfi Mahanani, 2014. Analisis Pengaruh Faktor Internal Dan Faktor Lingkungan Eksternal Terhadap Pelatihan wirausaha dan Minat Berwirausaha (Studi pada siswa SMA Negeri 1 Semarang). Jurnal Universitas Diponegoro Semarang.

Lee, M. S. (2005). Impact of Entrepreneurship Eduction: A Comparative Study of the US and Korea. International Entrepreneurship and Management Journal , 27-43

Linan, Francisco \& Leon, J. A. M. (2007) Entrepreneurial Intentions. Department of Apply Economy I, Universidad de Sevilla. Department of Social and Organizational Psychology. UNED

Purnamasari. Ika. 2012. Pengaruh Konsep Diri dan Peranan Keluarga terhadap Minat Berwirausaha Siswa Kelas XI di SMK Negeri 1 Singaraja tahun Ajaran 2011/2012. Skripsi (tidak diterbitkan). Jurusan Pendidikan Ekonomi, Fakultas Ilmu Sosial Undiksha

Putu Eka Desy Yanti, Made Nuridja, Ketut Dunia. 2014. Pengaruh dorongan Keluarga Terhadap minat Berwirausaha Siswa Kelas XI SMK Negeri 1 Singaraja. Jurnal Bisnis dan Manajemen Vol: 4 N0: 1 Tahun: 2014

Riduwan, 2005, Skala pengukuran Variabel-Variabel Penelitian, Cetakan Ketiga, Alfabeta, Bandung.

Sarwono, Sarlito W.. (2011). Psikologi Remaja (edisi revisi). Jakarta: Rajawali Pers.

Selnes, Fred (2008), "An Examination of the effect of Product Performance on Brand Reputation, Satisfaction and Loyalty", European Journal of Marketing, 27 (9). (19$35)$.

Singgih Purnomo, 2013. Analisis Pengaruh Faktor Keluarga, Pendidikan dan Lingkungan Terhadap Minat Berwirausaha Mahasiswa STMIK Duta Bangsa Surakarta. Program Studi Sistem Informasi STMIK Duta Bangsa Surakarta

Solomon, Michael (2006), Consumer Behavion, 3th edition, McGraw Hill.

Sugiyono, 2007. Metodologi Penelitian Bisnis, Cetakan Ketujuh, CV. Alpabeta, Bandung. 